\title{
Education, the New Science, and Improvement in Seventeenth-Century Ireland
}

John Patrick Montaño

\section{(2) OpenEdition \\ 1 Journals}

\section{Electronic version}

URL: http://journals.openedition.org/etudesirlandaises/5598

DOI: 10.4000/etudesirlandaises.5598

ISSN: 2259-8863

\section{Publisher}

Presses universitaires de Caen

\section{Printed version}

Date of publication: 18 December 2018

Number of pages: $25-36$

ISBN: 978-2-7535-7693-3

ISSN: 0183-973X

\section{Electronic reference}

John Patrick Montaño, «Education, the New Science, and Improvement in Seventeenth-Century Ireland », Études irlandaises [Online], 43-2 | 2018, Online since 01 November 2018, connection on 13 September 2019. URL : http://journals.openedition.org/etudesirlandaises/5598; DOI : 10.4000/ etudesirlandaises.5598 


\title{
Education, the New Science, and Improvement in Seventeenth-Century Ireland
}

\author{
John Patrick Montaño \\ University of Delaware
}

\begin{abstract}
Bacon and Hartlib were leaders of an empirically based movement that contributed to the transformation of reform strategies in Ireland. While continuing to rely on changes to land use their claims to scientific objectivity helped alter the reformers goal from civilizing Ireland to improving it by relying on the new learning of the Hartlib Circle. The support of Oliver Cromwell provided unprecedented opportunities to apply theories of political economy on the blank slate of Ireland's landscape.

Keywords: new science, Samuel Hartlib, Ireland, improvement, cultural resistance

\section{Résumé}

Bacon et Hartlib furent à la tête d'un mouvement empirique qui contribua à la transformation des stratégies de réforme en Irlande. Tout en continuant de dépendre des changements de l'usage de la terre, leurs revendications à l'objectivité scientifique aidèrent à faire évoluer le but final des réformateurs : au lieu de civiliser l'Irlande, l'améliorer en se basant sur le nouveau savoir du Cercle Hartlib. Le soutien d'Oliver Cromwell fournit des occasions sans précédents d'appliquer les théories d'économie politique à la page blanche qu'était le paysage de l'Irlande.

Mots clés : nouvelle science, Samuel Hartlib, Irlande, amélioration, résistance culturelle
\end{abstract}

Steven Shapin began his book on the New Learning by saying "there was no such thing as the Scientific Revolution, and this is a book about it." In the same way, there was no humanist-style revolution in education in the seventeenthcentury, yet this is a paper about its implications. It is clear that the writings of Sir Francis Bacon and others introduced a novel way of gathering and using

1. Research for this work was conducted in multiple archives in several countries and on two continents. None of that would have been possible without the generous support of the National Endowment for the Humanities, the Huntington Library, a University of Delaware's General University Research Grant, the Department of History's Research Fund and a Grant from the Center for Global and Area Studies: I am very grateful to each of these institutions. Professors John Brewer, Kathleen Wilson and Fiona Bateman have been loyal supporters of my work and my thanks remain constant. Joanne, Hektor and Carolina inspire me to continue working while providing incessant reasons not do so. Steven Shapin, The Scientific Revolution (London: The Univeristy of Chicago Press, 1996), 1. 
knowledge, fostering a new natural or mechanical philosophy that emphasized a new style of education aimed at the gentleman working in the service of the state- a disinterested thinker seeking knowledge for the sake of the common good and improvement of society. For Bacon, it was necessary "to try the whole thing anew upon a better plan, and to commence a total reconstruction of sciences, arts, and all human knowledge, raised upon the proper foundations." ${ }^{2}$ More importantly, Bacon aspired to create new methods that would produce a reformed knowledge and superior education that would prove worthy to be valued and supported by the state and other institutions of society. In short, new methods along with new men educated outside the university - men trained to take-up knowledge as an instrument of civic utility—would make the learning a more effective arm of state power. ${ }^{3}$

One point worth remembering without my truly it developing here is the importance of the general crisis in politics, society and culture following the Reformation; this widespread upheaval played a crucial role in contributing to the changing attitudes towards knowledge and in particular the relations between knowledge and social order. Indeed, a new method was viewed as a remedy for the problems of intellectual disorder, and the knowledge of nature in particular was considered deeply relevant to problems of order, not least because nature was understood to be a divinely authored book. Most importantly, a new method that relied on observation and reason was valued thanks to its claims to be objective and disinterested, making it a more valuable tool. Naturally, the capacity of knowledge to make valuable contributions to the world flows from an understanding that it was not produced to further particular human interests. With this in mind, the remainder of the essay will aim to look at how a few notable examples of the new types of knowledge and education were brought to bear on the strategies to order and to improve Ireland in the seventeenth century.

Bacon's essay Of Plantations and his involvement in the Articles of Plantation for Ulster are well known, but his influence is more apparent in the Cromwellian period and after. ${ }^{4}$ Part of Bacon's plan for reform was to secure order through means approved of and implemented by the state. In the Novum Organon he called for novel educational methods along with organized and collective labor, all

2. Quoted in ibid., 66.

3. Ibid., 127; Lisa Jardine and Michael Silverthorne, ed. The New Organon, Cambridge Texts in the History of Philosophy (Cambridge: Cambridge University Press, 2000), 27-31 and passim.

4. For Bacon's occasional works see James Spedding, ed. The Life and the Letters of Francis Bacon, 14 vols., vol. 4 (London: Longmans, 1868), Discourse on the Plantation in Ireland, 116-26; Francis Bacon, Lord Bacon's Essays, or Counsels Moral and Civil, 2 vols., vol. 1 (London1720), "Of Plantations", 211-19. See also the typically interesting reading in Willy Maley, “'Another Britain?’ Bacon's Certain Considertions Touching the Plantation in Ireland (1606; 1657)," in Nation, State and Empire in English Renaissance Literature: Shakespeare to Milton (Basingstoke: Palgrave, 2003), 93-112. 
supported by the government. In the New Atlantis Bacon has Solomon's House, a combination of bureaucratic and intellectual organization, a proto-research and engineering institute clearly intended to serve the interests of an imperializing state: the work done there was presented as powering the expansionist drive of the kingdom and consequently received huge resources from the state. ${ }^{5}$ In the event, several such intellectual associations or circles emerged under the early Stuarts, and Cromwell and others were to rely on their expertise when it came to dealing with the damnable question of Ireland. ${ }^{6}$

The Irish Rebellion of 1641 destroyed much of the material changes to the landscape introduced by the plantations. But Cromwell's conquest and confiscations provided the opportunity to impose order and civility once again. Surely the first stage in the process--the comprehensive defeat of the natives--was now complete. The improvement of Ireland was now the responsibility of men associated with the new learning, led by Samuel Hartlib. ${ }^{7}$ The Hartlib Circle had produced several tracts on husbandry and improvement in the 1630s and 1640s. Their association with the Independents in England meant that Cromwell's victory might permit the implementation of some of their schemes on the blank slate of Ireland. ${ }^{8}$ A cursory examination of some of the writings and proposals for the improvement of Ireland produced by these new scientists is intended to support the three suggestions offered here: that the new learning's views on economic improvement were informed by Renaissance and Classical assumptions about husbandry and cultivation; secondly, that they believed a civilized or enlightened society was rooted in private property, permanent dwellings, and enclosed fields; ${ }^{9}$ and finally that Irish hostility to, and destruction of, these markers of civilized identity convinced them that Irish pastoral society had to be replaced by a settled, civilized one before economic improvement could take place. ${ }^{10}$

5. Silverthorne, The New Organon; Jerry Weinberger, ed. New Atlantis and the Great Instauration, Crofts Classics. (Hoboken: Wiley, 2016).

6. Oana Matei, "Macaria and the Puritan Ethics of Direct Particiapation in the Transformation of the World," Society and Politics 5, no. 2 (2011).

7. Charles Webster, ed. Samuel Hartlib and the Advancement of Learning (Cambridge: Cambridge University Press, 1970), chapts. 2-4 and 7-8; Toby C. Barnard, "The Hartlib Circle and the Cult and Culture of Improvement in Ireland," in Samual Hartlib and the Universal Reformation: Studies in Intellectual Communication, ed. Michael Leslie Mark Greengrass, and Timothy Raylor (Cambridge: Cambridge University Press, 1994), 289-91.

8. John Adamson, "Strafford's Ghost: The British Context of Viscount Lisle's Lieutenancy of Ireland," in Ireland Fro Independence to Occupation 1641-1660, ed. Jane H. Ohlmeyer (Cambridge: Cambridge University Press, 1995), 132-48; Patrick Little, “The Irish 'Independents' Amd Viscount Lisle’s Lieutenancy of Ireland,” HJ 44, no. 4 (2001).

9. For my previous claims about the significance of cultivation and material culture in Tudor Ireland, see John Patrick Montaño, “'Dycheyng and Hegeying': The Material Culture of the Tudor Plantations in Ireland,” ed. Fiona Bateman and Lionel Pilkington (Houndsmill, Basingstoke: Palgrave Macmillan, 2011); The Roots of English Colonialism in Ireland (Cambridge: Cambridge University Press, 2011), chapts. 1-3, 5.

10. Raymond: Gillespie, "The Murder of Arthur Champion and the 1641 Rising in Fermanagh," Clogher Record 14, no. 3 (1993); John Patrick Montaño, "A Frank Exchange of Views: Communicating through Violence in Ireland, 1565-1610,” Études Irlandaises 42, no. 2 (2017). 
The opportunities offered by Cromwell's new dispensation in Ireland were like manna for the advocates of the new learning. The search for precise empirical knowledge of Ireland had begun before the civil war but was given new life by the Hartlib Circle. The shiring, mapping, and surveying of Ireland was pushed forward with renewed vigor, with Elizabethan servants producing a plethora of discoveries, accounts, descriptions, and views of Ireland. ${ }^{11}$ The earliest attempt to create accurate maps of lands beyond the pale was undertaken with the support of Sir William Cecil, though the constant disappearance of the cartographers limited the effectiveness of this project. ${ }^{12}$ Most importantly, one of the first expositions on the necessity "Of Plantations" was written by the father of the new science, Francis Bacon himself. But one of the distinguishing features of the new baconian science was its desire to gain control of the natural environment through improvement and technology. This endeavor served both spiritual and utilitarian purposes. Hartlibians accepted the puritan view of fallen man existing in an unfriendly environment, a mindset which convinced them that the godly man must labor to "correct" or improve nature as a means of atonement. ${ }^{13}$ Many of the adventurers who came to Ireland considered the pastoral society of the Irish as the perfect example of ungodly sloth and sin: an indolent people living passively on the earth, taking only what nature offered. The new devotees of reason and improvement believed this passivity blurred the distinction between man and beast. For them, Ireland was an island of savages and barbarians, a nation overdue for a sharp dose of physical and moral improvement. But before this could be undertaken, a reliable description of Ireland based on empirical observations and the latest technical knowledge was required.

Thanks to the efforts and influence of Hartlib just such an effort was sponsored by the Council of State, resulting in William Petty's Down Survey, the most thorough account of Irish topography ever attempted. Petty drew upon the most advanced scientific and technical methods available in the seventeenth century, relying heavily on members of the Hartlib group. ${ }^{14}$ In addition to the instruc-

11. Roots of Colonialism, chapts. 3-4; G. A. Hayes-McCoy, "Contemporary Maps as an Aid to Irish History, 15931603,” Imago Mundi 19 (1965); John H. Andrews, “The Mapping of Ireland's Cultural Landscape, 15301630," in Gaelic Ireland: C.1250-C.1650: Land, Lordship and Settlement, ed. David Edwards and Elizabeth FitzPatrick Patrick J Duffy (Dublin: Four Courts Press, 2001); J. H. Andrews, Rolf Loeber, "An Elizabethan Map of Leix and Offaly: Cartography, Topography and Architecture," in Offaly: History and Society, ed. William Nolan \& Timothy O’Neill (Templeogue, Dublin: Geography Publications, 1998); Annaleigh Margey, "Surveying and Mapping Plantation in Cavan, C. 1580-1622," in Culture and Society in Early Modern Breifne / Cavan, ed. Brendan Scott (Dublin: Four Courts Press, 2009).

12. Andrews. J. H., The Queen's Last Mapmaker: Richar Bartlett in Ireland, 1600-03 (Dublin: Geography Publications, 2008), chapt. 4.

13. Matei, "Macaria and Puritan Ethics," 52-55.

14. Sir William Petty, The History of the Survey of Ireland Commonly Called the Down Survey, A.D. 1655-1656. (New York: A.M. Kelley, 1857); Ted McCormick, William Petty and the Ambitions of Political Arithmetic (Oxford: Oxford University Press, 2009), chapt. 3; Adam Fox, "Sir William Petty, Ireland, and the Making of a Political Economist, 1653-87,” The Economic History Review 62, no. 2 (2009). 
tions supplied by Petty, the surveyors were given standardized tools and training, a survey course by Miles Symner at Trinity, and instructions to ensure consistency and accuracy in their endeavors. ${ }^{15}$ The empirical approach, the modern instruments, the recording of data in uniform folios provided by Petty and placing the findings "down" on a map, are all examples of the new scientific skills advocated by the Hartlib Circle and the new education. But if the skills and methods were new and improved, the goals of the modern scientists displayed a considerable continuity with the Renaissance adventurers who had preceded them in Ireland. Petty joined a chorus of previous reformers who condemned the primitive and impermanent architecture of the natives as a symbol of the indolent and unsettled lifestyle. For this reason, building with brick or stone and mortar was urged: sturdy dwellings were an important sign of the adoption of the new learning and the English style of order. ${ }^{16}$

After 1555, the outpouring of husbandry manuals and agricultural treatises inspired by the translation of the Foure Bokes of Husbandry helped to establish the relationship between civility, gentility, and husbandry. This further inspired the belief that the socio-economic conditions in Ireland were the root of all evil there. The Hartlibians further believed that agricultural and spiritual reform were linked. The efficient husbandman was a common metaphor for puritans, and in 1652 Dury \& Hartlib published The reformed Spiritual Husbandman. The next year saw Ralph Austen's, A treatise on fruit trees. together with the spiritual use of an orchard. held forth in divers similitudes between natural and spiritual fruit trees. ${ }^{17}$ These ideas come from Bacon's idea that a great co-operative effort to marshal empirical knowledge would help restore man's dominion over nature which had been sacrificed at the Fall. ${ }^{18}$ This interventionist attitude toward nature justified the construction of an improved, man-made landscape. So before the Irish could embrace the spiritual reforms on offer, Ireland would have to be remade as an ordered society based on well-bounded agricultural plots and solid masonry. Conveniently enough, the precise technical survey being taken down would also help to identify the best land available.

Prominent among Petty's Instructions for surveying and admeasuring the Lands in Ireland was the command that "distinction be made betweene the profitable and unprofitable parts...[and] whether the profitable be arable, meadow,

15. T. C. Barnard, "Miles Symner and the New Learning N Seventeenth-Century Ireland," JRSAI 102 (1977): 291-94; Barnard, "Hartlib and Improvement."

16. Sir William Petty, Tracts, Chiefly Relating to Ireland (London, 1769), "Politcal Economy of Ireland,” 109.

17. Samuel and John Dury Hartlib, The Reformed Spiritual Husbandman . . . (London, 1652); Ralph Austen, $A$ Treatise on Fruit Trees... Together with the Spiritual Use of an Orchard. Held Forth in Divers Similitudes between Natural and Spiritual Fruit Trees (Oxford, 1657); Webster, Hartlib and Learning, 165-91.

18. Hartlib and Learning, 3-5. 
or pasture."19 Reforms and improvement were genuinely desired by some, while opportunism, ambition and the search for profit drove others. Yet they all agreed that the mobile pastoral society of the native Irish could not coexist with the tenant-based, individual agricultural units of the arriving settlers. Within years Petty would offer a solution for native idleness through a public works project which would simultaneously give Ireland a more civilized, modern landscape. The "spare hands" of the idle, "(besides the making of Bridges, Harbors, Rivers, High-ways,) are able to plant as many Fruit and Timber Trees and also Quick-set Hedges as being grown up, would distinguish the Bounds of Lands, beautifie the Countrey, shade and shelter Cattel, furnish Wood, Fuel, Timber and fruit, in a better manner than ever was yet known in Ireland or England." ${ }^{20}$ Beyond their concern for idle hands, these new scientific ideals remained tied to notions of civility, culture, and cultivation. Significantly, more and more of the improvements were directed almost exclusively at Irish land, the people becoming increasingly invisible as nature was emphasized according to the latest educational ideals. Ireland's transition from barbaric to civilized continued to look like the transformation of an open pastoral landscape into a divided agricultural one. At the heart of all of this would be gardens and parks as evidence of having tamed a wild and menacing environment. Thus, new crops, new methods, selected livestock, land drainage, reclamation, manuring, emparking, and enclosing with hedges, ditches, palings, and walls and massive deforestations would join with the new towns to proclaim the distinctive (and superior) values of the newcomers. ${ }^{21}$

An early example of the novel educational ideas was provided by Samuel Hartlib in $1641 .^{22}$ His ostensibly utopian Description of the Famous Kingdome of $M A C A R I A$ drew upon the models of Bacon as well as Roman ideas about colonies but was in fact a thinly-veiled practical program for the improvement of newly acquired lands. Applying Roman colonial theory to individuals, Hartlib reported that in Macaria, if any man holdeth more land than he is able to improve to the utmost, he shall be admonished . . . and if he doth not amend his husbandry within a yeares space, there is a penalty set upon him, which is yearly doubled till his lands be forfeited, and he banished out of the Kingdom." ${ }^{23}$ The failure to "improve" your land, or in this case, to farm it in the English manner,

19. Petty, Down Survey, 47.

20. A Report from the Council of Trade in Ireland, to the LL and Council, which was drawn by Sir William Petty, Consideration relating to the Improvement of Ireland, 217, in Tracts.

21. T. C. Barnard, "Gardening, Diet and 'Improvement' in Later Seventeenth-Century Ireland," Journal of Garden History 10, no. 1 (1990): 77-81.

22. Samuel Hartlib, A Description of the Famous Kingdome of Macaria... (London, 1641); Charles Webster, "The Authorship and Significance of Macaria," P \& P 56 (1972). Compare this with attitudes in Sir Thomas More, Utopia, trans. Robert M. Adams, Norton Critical Editions (New York: W. W. Norton \& Co., 1975), 45.

23. Hartlib, Macaria, 5. 
was here established as a justification for dispossession. MACARIA was offered as an Example to other Nations with councils and tax policies directed squarely towards the scientific improvement of the natural world. Beyond its Great Council there were five "under-councils" for "Husbandry, Fishing, Trade by Land, Trade by Sea, and for new Plantations," just the sort of state-sponsored institutions recommended by Bacon. For Hartlib and his followers, husbandry was the basis of plenty and prosperity, and therefore essential to supporting the number of people necessary for trade and commerce: "except Husbandry be improved, the Industrie of Trading . . can neither be advanced or profitably upheld." ${ }^{24}$ This conviction was common to the new political economists, William Petty in particular. In order to expedite the spread of economic improvements in MACARIA, "the twentieth part of every mans goods that dieth shall be employed about the IMPROVING of lands, and making High-wayes faire, and bridges over rivers; by which means the whole Kingdome is become like a fruitful Garden." ${ }^{25}$

The use of confiscation in probate was meant to maximize the number of acres under the plough, thereby laying the foundation for economic improvements. But plantations in Ireland over the last century had made clear that not all Irish acres were created equal. As a result, before Hartlib's Macarian example could be followed, an exact reckoning of Ireland's land and resources was imperative. The obsession here with agriculture and husbandry was not at all new, though thanks to the new educational ideas the empirical and technical methods used to gather information about Ireland certainly were. ${ }^{26}$ But despite the advanced techniques of the new science, the economic improvements planned were predicated on the need to eliminate the pastoral society of the natives. Throughout these years, the proper use of land was taken as the key signifier of civility. ${ }^{27}$

Hartlib found an excellent source for the information desired in the unfinished work of Gerard Boate. The first volume of his Naturall History of Ireland was published posthumously, with a dedication by Hartlib, who tried for years to gather additional material for later volumes by circulating a list of "Interrogatories," but the responses were never sufficient to complete the work. He still felt the need to publish the first part as "a True and ample Description of the several ways of Manuring and Improving" Ireland. Beyond scientific benefits and

24. Dedication to Cromwell and Fleetwood, Commander in Chief in Ireland, by Samuel Hartlib, in Gerard Boate, Irelands Naturall History. Being a True and Ample Descritption Of. . The Several Ways of Manuring and Improving the Same.... For the Common Good of Ireland, and More Especially, for the Benefit of the Adventurers and Planters Therein (London: Published by Samuell Hartlib, 1657), sig. a3.

25. Hartlib, Macaria, 3.

26. Charles Webster, Utopian Planning and the Puritan Revolution: Gabriel Plattes, Samuel Hartlib and Macaria (Oxford: Wellcome Unit for the History of Medicine, 1979); "Macaria, Samuel Hartlib and the Great Instauration," Acta Comeniana 26 (1979).

27. Montaño, Roots of Colonialism, 1-21. 
the common good of Ireland, the title page freely admitted that the work was intended "for the benefit of the Adventurers and Planters therein." ${ }^{28}$ The Naturall History provides clear evidence of the link between education, agriculture, improvement, and cultural differences exposed by the imperial process. Boate wrote in the aftermath of the Irish Rebellion of 1641, and that experience surely informs his entire work. Interestingly enough, the History also demonstrates how readily the Irish identified the ways in which agricultural improvements threatened their society and culture. Indeed, nothing outraged Boate more than the Irish rejection of the civility on offer and their determination to sweep it away in all its manifestations. $^{29}$

Boate was convinced that husbandry was the surest path to the perfection of earthly benefits, "and in the management thereof by way of Trading." Hartlib agreed with this in his Dedication, telling Cromwell and Fleetwood that he knew "nothing more useful than to have the knowledge of the Naturall History of each Nation advanced . . . otherwise there can be no Industrie used towards the improvement and Husbandry thereof." ${ }^{30}$ But for Hartlib as for Boate the improvements in Husbandry were very much a part of the civilizing and improving process central to imperialism. Indeed, one of the subjects of the later volumes was to have been the "great paines taken by the English, ever since the Conquest, to civilize [the Irish], and to improve the Countrie." ${ }^{31}$ For centuries civilizing Ireland had been equated with pacifying Ireland. But by the mid-seventeenth century civility was firmly associated with cultivation, and the introduction of cultivated plots seen as the essential building blocks of an ordered, rational society that justified imperial expansion. ${ }^{32}$ The fact that conversion of confiscated pasture land into enclosed fields led to considerable personal gain only proved that the instruments of providence were reliably rewarded. ${ }^{33}$

For advocates of the new science, God manifested himself in nature and in human Learning, and it was one of the great failings of the Irish that they allowed so much of their country to lay watery and waste "through their carelessness, wherby all or most of the Bogs at first were caused." ${ }^{34}$ This state of affairs was particularly galling to a Dutchman like Boate. He insisted that the excessive moisture which plagued Ireland could be reduced "by the industry of men, if the country being once inhabited throughout by a civill Nation." ${ }^{35}$ The draining of Irish bogs

\footnotetext{
28. Boate, Naturall History.

29. See below, pp. 12-13.

30. Boate, Naturall History, Dedication, sig, a3.

31. Ibid., sig. a6v.

32. Montaño, Roots of Colonialism.

33. The earl of Cork's motto was: God's Providence is Mine Inheritance.

34. Boate, Naturall History, 113.

35. Ibid., 169.
} 
may have been a fanciful idea in the 1650s, but the point to notice is the belief in the ability of "civil men" to make Ireland into a productive and wealthy nation. Boate's descriptions of clearing fields, building roads, erecting fences, and draining bogs were intended as proof that the English were "the introducers of all good things in Ireland." More importantly, Boate recognized that the key indicators of economic improvement and civility in Ireland were "building, planting, hedging, and the like, but chiefly with [new] kinds of manuring." ${ }^{36}$ By the 1650 s the ideas of the new science had provided considerable credibility for an ideology which saw landscapes and land use as a means of distinction, a means of expressing the values of a society. Furthermore, an ordered and settled landscape was a marked sign of the improved conditions in Ireland. In this case the English value being expressed is the valorization of order, particularly an order that serves as an assertion of imperial authority. ${ }^{37}$ Similarly, the alteration of a landscape may be viewed as a process that validates and legitimates power or as the method people use to transform the natural world into cultural realms of meaning. As a result, agricultural improvements and changes in the land become important sites where cultures and values are expressed, but also contested.

Accordingly, the native inhabitants were well aware of the significance of the "improvements" which were appearing throughout the country. Castles, forts, and walled towns were the most glaring examples of the new civilized identity being implanted. But these sturdy defensive structures were by no means the sole expression of the new and improved order being constructed in Ireland. The fields, fences, hedges, ditches, and walls were easily recognized as the borders and barriers they were meant to be. It should come as no surprise that the rebellion of 1641 witnessed widespread assaults on these monuments to civility and improvement. Boate complained bitterly of Irish ingratitude, reporting English improvements "for which that brutish nation from time to time hath rewarded them with unthankfullness, hatred, and envy, and lately with a horrible and bloody conspiracie, tending to their utter destruction." ${ }^{38}$ In John Temple's account of the Irish rebellion he acknowledges the native desire to destroy in symbolic fashion everything that reminded them of the English presence in the country. Thereby communicating their hostility fo the cultural markers being planted in the landscape. The lamentations about these attacks reveal how accurately the Irish identified the signs produced by the new science and education:

Not content to have murthered or expelled their English neighbours ... they endeavoured quite to extinguish the memory of them, and of

36. Ibid., 114, 97-8.

37. Barnard, "Hartlib and Improvement," 284-87; Webster, Utopian Planning; "Macaria, Samuel Hartlib and the Great Instauration.”

38. Boate, Naturall History, 114. 
all the civility and good things by them introduced amongst that wild Nation; and consequently in most places they did not only demolish the houses built by the English, the Gardens and Enclosures made by them, the Orchards and Hedges by them planted, but destroyed whole drove and flocks of ENGLISH Cowes and Sheep. ${ }^{39}$

The evidence for similar attacks on the material aspects of agricultural improvements is common in the years of relative tranquility from 1610-40. It seems that both sides were well aware of the role which land use and material culture played in distinguishing their incompatible societies. The tidy inclosed plots proved regular and easy targets, tokens of change that could be could be demeaned on a daily basis. One early improver complained bitterly about an annoying habit of his neighbors:

For an instance of theire malice to the Englishe, an English man did strongly inclose a peece of ground for meadowe, and hee pitched out from thence an exceeding nomber of stones, and when he came to mowe his grounds he found more stones then he tooke out (for the Irish never went that way, day or night) but threwe in stones from under their mantles. ${ }^{40}$

On the English side, the absence of improvements was taken for a sign of the sloth and barbarism which the new settlers aimed to eliminate. Constructing a substantial stone house, orchard and gardens amidst a re-ordered and improved landscape were the most visible components of the civilized, enlightened identity which separated old from new. For the improvers,

it tasts of the savage to see an ancient estated family continue to live in the country on their lands, yet without a tolerable habitation: without the decorums of garden: without meadow and enclosed pastures; without the coverture and embellishment of quicks and trees: without in fine anything that may speak of a gentle and wise economy. ${ }^{41}$

The "wise economy" craved by the settlers was based on assumptions about the merits of husbandry and the subjugation of the natural world so crucial to the new educational ideals. Enlightened man would rely on the new learning to advance husbandry. The remodeled landscape and the consequent peace and stability would create an environment in which manufacturing and trade would

39. Ibid., 89.

40. Huntington Library, in Ellesmere MSS (San Marino, California), 1746, fo. 12; D. J. Mattingly, Imperialism, Power, and Identity (Princeton: Princeton University Press, 2011), 57-72.

41. Huntington Library, Ellesmere, 1737, fo. 17 
flourish. The civilized example of husbandry and permanent dwellings was the best way to "transmute" the Irish.

As early as 1641, John Temple mistakenly assumed that "these people of late times were so much civilized by their cohabitation with the English ... . [that] many Irish, especially of the better sort, have taken up the English language, apparel, and decent manner of living in their private houses." ${ }^{2} 2$ Apparently he was soon to be disabused of this notion. The attacks in 1641 on English towns, buildings, boundaries, and all enclosed lands had demonstrated the natives' hostility to the improved landscape.

Cromwell's transplantations to Connaught proved one more failed solution; and by the 1670s it was a commonplace that the pastoral society of the "wild Irish" was the number one obstacle to the improvements desired. Petty's scientific observations convinced him that forcing the Irish to live like the English would simultaneously eliminate their barbarous culture, provide jobs, and create the wealth necessary to sustain industry. Petty felt the government could "create jobs for Idle hands and wealth through building of 168,000 small Stone-wall Houses, with chimneys, Doors, Windowes, Gardens and Orchards, ditch'd and quicksteed; instead of the lamentable Sties now in use... The planting 5 Millions of FruitTreees...The planting 3 Millions of Timber-Trees upon the Bounds and Meers of every [plot]." ${ }^{43}$ By forcing the Irish to live in the English manner, Petty believed they would inevitably be transmuted into the civilized farmers who would live in stone houses and generate the wealth necessary for advancing Irish trade. In the end, Petty even proposed that single Irish women be forced to marry English men, and raise their families in the English manner, for "when the Language of the Children shall be English, and the whole Oeconomy of the Family English, viz. Diet, Apparel, \&c the Transmutation will be very easy and quick." Imposing English husbandry, language, law, architecture, and culture on Ireland was accepted as the necessary precursors to introducing order and civility. For William Petty economic improvement was more reliable than "all Military means of setling and securing Ireland in peace and plenty." ${ }^{34}$ Economic improvements-in the form of a settled agricultural society-were the key to the emergence of a civilized and enlightened Ireland. Since civility needed to precede religious conversion, economic improvements offered the Irish a most desirable combination: material gain in tandem with spiritual salvation.

Here again we see the new learning linking economic improvement and a civilized identity to the elimination of the existing Irish customs and society. For

42. Temple. quoted in Nicholas Canny, The Upstart Earl: A Study of the Social and Mental World of Richard Boyle First Earl of Cork, 1566-1643 (Cambridge: Cambridge University Press, 1982), 138.

43. Petty, Tracts, "Political Economy of Ireland," 109.

44. Ibid., 321. 
individuals, there were tremendous gains to be had from the economic improvements proposed. But for the government the improvements and civility desired were a means to remove the mobile, pastoral, society which had resisted English offers of peace and order for five centuries. Advocates of the new education and learning offered economic improvement as the means to create a new, enlightened identity for Ireland. But the emphasis on cultivation and agriculture meant that the Irish people were reduced a secondary concern. The appropriate social and economic attitudes toward land and settlement would have to come first. With the natural world properly subdued, the population could choose between husbandry or Connaught. 